\title{
Seroepidemiology of infectious bovine rhinotracheitis infection in unvaccinated cattle
}

\author{
M. Saravanajayam ${ }^{1}$, K. Kumanan ${ }^{2}$ and A. Balasubramaniam ${ }^{1}$
}

1. Veterinary University Training and Research Centre, Perambalur - 621 220, Tamil Nadu, India; 2. Tamil Nadu Veterinary and Animal Sciences University, Chennai - 600 051, Tamil Nadu, India.

Corresponding author: M. Saravanajayam, e-mail: saravet78@gmail.com, KK: kumananrani@hotmail.com, AB: balasubramaniam72@gmail.com

Received: 10-08-2015, Revised: 31-10-2015, Accepted: 07-11-2015, Published online: 18-12-2015

doi: 10.14202/vetworld.2015.1416-1419 How to cite this article: Saravanajayam M, Kumanan K, Balasubramaniam A (2015) Seroepidemiology of infectious bovine rhinotracheitis infection in unvaccinated cattle, Veterinary World 8(12): 1416-1419.

\begin{abstract}
Aim: The present study aimed to investigate the seroepidemiology of infectious bovine rhinotracheitis (IBR) infection in the non-vaccinated cattle population in northern part of Tamil Nadu, India.

Materials and Methods: A total of 255 sera samples were collected from cattle having the history of respiratory and reproductive disorder from cattle of different age, breeds, and sex. All the sera samples were subjected to indirect ELISA for the diagnosis of IBR antibodies.

Results: Results revealed that the seroprevalence of IBR infection among non-vaccinated cattle population was of $65.88 \%$. No significant difference was noticed in the prevalence of IBR infection between cattle showing respiratory (63.64\%) and reproductive form $(70.89 \%)(\mathrm{p} \geq 0.05)$. A higher prevalence was noticed in animals above 3 years of age $(59.60 \%)$ and in crossbred animals $(71.26 \%)$ than young and non-descript animals. This study showed the higher prevalence of IBR infection in female $(67.92 \%)$ than in male $(33.33 \%)$.
\end{abstract}

Conclusion: Cattle population in this part can better be protected with vaccination than leaving them unvaccinated and seromonitoring shall have to be stressed with regular attempts to isolate and characterize the causative agent for IBR.

Keywords: cattle, enzyme-linked immunosorbent assay, infectious bovine rhinotracheitis, prevalence.

\section{Introduction}

Infectious bovine rhinotracheitis (IBR) caused by bovine herpesvirus Type 1 (BHV1) is a common cattle disease which is responsible for the significant huge economic loss in dairy industry worldwide. Infection with BHV-1 is associated with mild to severe respiratory disease and represents a high-risk for bovine respiratory disease complex. Infections with this agent can also manifest as ocular, neonatal, gastrointestinal, and neurologic disease as well as reproductive failure due to abortion and other genital symptoms (infectious pustularvulvovaginitis (IPV) and infectious pustularbalanoposthitis (IPB) $[1,2]$. Though the disease is essentially a herd problem, occurs mostly in animals over 6 months of age. Transmission occurs normally by contact with infected animals, aerosol route and virus-contaminated semen from BHV-1 infected bulls. A complication associated with IBR infection is the ability of the virus to establish latency unless stress conditions favor its reactivation [3].

Indirect enzyme-linked immunosorbent assay (ELISA) has been extensively used for the assessment of seroepidemiological investigation of IBR antibodies among the cattle population in the various parts of the world [1,4-7].

Copyright: The authors. This article is an open access article licensed under the terms of the Creative Commons Attributin License (http:// creative commons.org/licenses/by/2.0) which permits unrestricted use, distribution and reproduction in any medium, provided the work is properly cited.
In the current study, the intensive management system of cattle population without IBR vaccination and frequent movement of animals between different places were the factors taken into the account to study the prevalence of IBR infection. Hence, the present study analyzed the prevalence of IBR infection among cattle population in organized farms as well as cattle brought to the Madras Veterinary College Hospital and Saidapet Polyclinic, Chennai and relationship of disease prevalence with respect to age, breed and sex were assessed simultaneously. Since, seroepidemiology of IBR was carried out the $1^{\text {st }}$ time in this region, the paired sera sampling and consideration of latent carriers were not done.

\section{Materials and Methods}

\section{Ethical approval}

All the protocols were as per the Committee for the Purpose of Control and Supervision of Experiments on Animals guidelines and approved by the Institutional Animal Ethics Committee of Madras Veterinary College.

\section{Place of work}

The study was conducted at the Department of Veterinary Epidemiology and Preventive Medicine with the help of Department of Animal Biotechnology, Madras Veterinary College, Tamil Nadu Veterinary and Animal Sciences University, Chennai, Tamil Nadu, India. 


\section{Antigen and known sera samples}

The BHV-1 strain BFA-OCS-W was passaged in Madin-Darby bovine kidney (MDBK) cell line used as a standard virus for antigen preparation. OIE international standard sera for IBR that include IBR-EU1 serum (strong positive) and IBR-EU3 serum (negative) from bovine origin received from Central Institute for Animal Disease Control Lelystad, The Netherlands, were utilized for this study as an internal control.

\section{Sera samples}

A total of 255 cattle sera samples for which the details are given in Tables-1-4 were drawn from the organized farms as well as cattle brought to Madras Veterinary College Hospital and Saidapet Polyclinic, Chennai with the history of respiratory and reproductive disorders and the samples were considered as representative for the cattle population in the study area.

\section{Titration of the BHV1}

About $50 \mu \mathrm{l}$ of MDBK cell suspension with $50 \mu \mathrm{l}$ of growth medium were dispersed into the 96 well tissue culture plates. After confluent monolayer formation, the growth medium was removed and inoculated with $50 \mu 1$ of tenfold dilution of BHV-1 using three wells per log dilution of virus. The plate was kept at $37^{\circ} \mathrm{C}$ for $1 \mathrm{~h}$ for adsorption of the virus into the cells

Table-1: Prevalence of IBR antibodies with respect to history of respiratory and reproductive infection in cattle.

\begin{tabular}{lccc}
\hline Type of infection & $\begin{array}{c}\text { No. of } \\
\text { sera } \\
\text { tested }\end{array}$ & $\begin{array}{c}\text { No. of } \\
\text { positives }\end{array}$ & $\begin{array}{c}\text { Percentage } \\
\text { of positives }\end{array}$ \\
\hline Respiratory infection & 176 & 112 & $63.64^{*}$ \\
Reproductive infection & 79 & 56 & $70.89^{*}$ \\
\hline
\end{tabular}

*No significant difference between respiratory and reproductive form $(p \geq 0.05), I B R=$ Infectious bovine rhinotracheitis

Table-2: Age wise prevalence of IBR antibodies in cattle.

\begin{tabular}{lccc}
\hline $\begin{array}{l}\text { Age } \\
\text { (year) }\end{array}$ & $\begin{array}{c}\text { No. of sera } \\
\text { tested }\end{array}$ & $\begin{array}{c}\text { No. of } \\
\text { positives }\end{array}$ & $\begin{array}{c}\text { Percentage } \\
\text { of positives }\end{array}$ \\
\hline Below 1 & 18 & 5 & $27.78^{*}$ \\
$1-3$ & 21 & 11 & 52.38 \\
$3-6$ & 104 & 71 & $68.27^{*}$ \\
Above 6 & 112 & 81 & $72.32^{*}$ \\
\hline
\end{tabular}

*Significant difference noticed between the age groups of below 1 year and 3-6 years, below 1 year and above 6 years $(p<0.01), I B R=$ Infectious bovine rhinotracheitis and then the virus inoculum was removed and added with $100 \mu 1$ of maintenance medium to each well. The plate was read for the degree of CPE and TCID ${ }_{50}$ was calculated 7 days post-infection [8]. Confirmation of virus was made by hematoxylin and eosin staining of BHV-1 infected MDBK coverslips.

\section{ELISA}

ELISA is a sensitive and specific test for assessing the antibodies for any diseases. Moreover, ELISA is prescribed a test for detecting IBR antibodies as per OIE.

\section{Preparation of antigen}

BHV-1 infected monolayer with tissue culture fluid in Roux flask was harvested by freezing and thawing thrice. Then, the fluid was centrifuged at $5000 \times \mathrm{g}$ for $10 \mathrm{~min}$ at $4^{\circ} \mathrm{C}$ to remove the cell debris. The supernatant fluid was sonicated for 5 times $(1 \mathrm{~min}$ at a time with an interval of 1 min each) under ice pack with an ultrasonic disintegrator (BransarSonifier 450).

Again the tissue culture fluid was centrifuged at $5000 \times \mathrm{g}$ for $30 \mathrm{~min}$ at $4^{\circ} \mathrm{C}$. The supernatant was collected in ultracentrifuge tubes and centrifuged at $1,00,000 \times \mathrm{g}$ for $1 \mathrm{~h}$ at $4^{\circ} \mathrm{C}$. The resulting pellet was resuspended to $1 / 5^{\text {th }}$ volume of phosphate buffer saline ( $\mathrm{pH}$ 7.2) and stored at $-20^{\circ} \mathrm{C}$. A control antigen was prepared in a similar manner from non-infected MDBK cells. The estimation of protein concentration was done for both the test and control antigen [9].

The optimum concentrations of coating antigen, sera dilution, antibovineIg G-HRP conjugate were standardized by the checkerboard titration as 1:50, $1: 10$ and 1:50, respectively. Indirect ELISA [10] was performed with slight modification.

The mean optical density (OD) value which was twice and above the negative OD value was taken as positive. The control positive and negative sera used were OIE IBR reference sera.

\section{Statistical analysis}

The data obtained from this study were statistically analyzed using Student's $t$-test [11].

\section{Results}

Propagation and titration of BHV-1

The final titer of $10^{6.362} \mathrm{TCID}_{50}$ per $50 \mu \mathrm{l}$ of the BHV-1 was obtained after four serial passages in MDBK cell line which was used for performing the

Table-3: Breed wise prevalence of IBR antibodies in cattle.

\begin{tabular}{lcccc}
\hline Breed & No. of sera tested & No. of positives & Percentage of positives & Overall percentage \\
\hline Crossbred & 127 & 90 & 70.87 & $71.26 *$ \\
$\quad$ Jersey Crossbred & 47 & 34 & 72.34 & $54.32 *$ \\
$\quad$ Holstein Friesian Crossbred & & & 52.94 & \\
Native breeds & 34 & 18 & 60.00 & \\
$\quad$ Murrah & 20 & 14 & 51.85 & \\
Surti & 27 & & & \\
$\quad$ Non-descript & & & & \\
\hline
\end{tabular}

*The prevalence rates are significantly higher in crossbred animals than indigenous breeds $(p<0.01), I B R=$ Infectious bovine rhinotracheitis 
indirect ELISA in this study. Characteristic CPE was observed in the cell line 2 days post-infection with BHV-1.

\section{ELISA}

The protein concentration of BHV-1 tissue culture antigen was found $0.6 \mathrm{~g}$ per $100 \mathrm{ml}$ [9]. The mean OD value of known negative serum (IBR-IU3) was 0.080 , twice $(0.160)$, and above this OD value was taken as positive.

Among 255 sera samples were screened from cases of cattle brought to the clinics and cattle in organized farms, 168 samples $(65.88 \%)$ were found to be positive for IBR antibodies by indirect ELISA. The results are shown in Table-5.

\section{IBR antibody prevalence in the animals with history of suspected signs}

Albeit there are reports in other parts of the country, this is the first report about the prevalence of IBR antibodies in this region. The prevalence of IBR antibodies based on the history of respiratory and reproductive disorders were $63.64 \%$ and $70.89 \%$, respectively, (Table-1). Analysis of data revealed that no significant difference in prevalence of IBR antibodies existed between the prevalence of respiratory and reproductive disorders $(\mathrm{p} \geq 0.05)$.

\section{Age wise prevalence}

In the present study, the differences in IBR prevalence rate between below 1 year and 1-3 years groups was not significant, whereas between below 1 year and 3-6 years and above 6 years groups were highly significant $(p<0.01)$ and the results were depicted in Table-2.

\section{Breed wise prevalence}

The breed wise prevalence of IBR antibodies were $71.26 \%$ and $54.32 \%$ in crossbred cows (Jersey Crossbred and Holstein Friesian Crossbred) and native buffalo breeds (Murrah, Surti and non-descriptive), respectively, (Table-3). The prevalence was

Table-4: Sex wise prevalence of IBR antibodies in cattle.

\begin{tabular}{lccc}
\hline Sex & $\begin{array}{c}\text { No. of sera } \\
\text { tested }\end{array}$ & $\begin{array}{c}\text { No. of } \\
\text { positives }\end{array}$ & $\begin{array}{c}\text { Percentage } \\
\text { of positives }\end{array}$ \\
\hline Male & 15 & 5 & $33.33^{*}$ \\
Female & 240 & 163 & $67.92^{*}$ \\
\hline
\end{tabular}

*The prevalence rates are significantly higher in female animals than male $(p<0.01)$, IBR $=$ Infectious bovine rhinotracheitis significantly higher in crossbred animals than indigenous breeds $(\mathrm{p}<0.01)$.

\section{Sex wise prevalence}

The prevalence of IBR antibodies in male and female that differed significantly $(p<0.01)$ were $33.33 \%$ and $67.92 \%$, respectively, as shown in Table- 4 .

\section{Discussion}

The prevalence of IBR antibodies among cattle population reared in part of south India was confirmed. As per the earlier reports in India, 56.5\% positive reactors in various parts of India and also $64.7 \%$ positives in Andhra Pradesh were recorded [12,13]. IBR infection was noticed with high prevalence among cattle reared as large herd [14].

\section{IBR antibody prevalence in the animals with history of suspected signs}

The higher prevalence in reproductive disorder was probably due to natural service by infected bulls and artificial insemination with infected semen $[1,2,15]$. The respiratory form of prevalence was due to the frequent introduction of cattle from various parts of the country and intensive management practices of cattle $[16,17]$.

\section{Age wise prevalence}

The age wise prevalence to IBR infection denoted that there was an increasing trend in the occurrence of IBR infection as age advances, and prevalence was low in the young animals $[5,18,19]$. In the present study, it is revealed that the prevalence of IBR in animals over 3 years of age was found to be higher than the lower age groups.

\section{Breed wise prevalence}

All breeds are susceptible [20] and the native breeds were comparatively less susceptible which is possibly due to their inherent resistance to infection.

\section{Sex wise prevalence}

The high prevalence in female might be attributed to the use of infected bulls for natural service and infected semen for artificial insemination [15,21-23].

\section{Conclusion}

The current study on the seroepidemiology of IBR infection revealed that unvaccinated cattle in northern part of Tamil Nadu were exposed to BHV-1. In conclusion, the cattle population in this part can better be protected with vaccination than

Table-5: Prevalence of IBR antibodies in cases attended clinics and Dairy Cattle in organized farms.

\begin{tabular}{lccc}
\hline Name of the place & No. of sera tested & No. of positives & Percentage of positives \\
\hline Madras Veterinary College Hospital, Chennai- 7. & 142 & 97 & 68.31 \\
Saidapet Polyclinic, Chennai & 12 & 8 & 66.67 \\
Livestock Research Station, Kattupakkam & 75 & 48 & 64.00 \\
Private Dairy Farm, Chennai District & 12 & 8 & 66.67 \\
Private Diary Farm, Thiruvallur District & 14 & 7 & 50.00 \\
Total & $255^{*}$ & 168 & 65.88
\end{tabular}

*No significant difference in the prevalence of IBR antibody among the serum samples collected from different sources $(p \geq 0.05)$, IBR=Infectious bovine rhinotracheitis 
leaving them unvaccinated and sero-monitoring shall have to be stressed with regular attempts to isolate and characterize the causative agent for IBR to minimize the economic loss in dairy farming arising out of IBR.

\section{Authors' Contributions}

MS planned the study design, collected and examined the samples. KK carried out the cell culture work and $\mathrm{AB}$ drafted and revised the manuscript. All authors read and approved the final manuscript.

\section{Acknowledgements}

The authors are thankful for funding by Tamil Nadu Veterinary and Animal Sciences University and Department of Animal Biotechnology, Madras Veterinary College, Chennai to carry out this work.

\section{Competing Interests} interests.

The authors declare that they have no competing

\section{References}

1. Bosco Cowley, D.J., Clegg, T.A., Doherty, M.L. and More, S.J. (2011) Aspects of bovine herpesvirus-1 infection in dairy and beef herds in Republic of Ireland. Acta Vet. Scand., 53: 40.

2. Gould, S., Cooper, V., Reichardt, N. and O'Connor, A. (2013) An evaluation of the prevalence of bovine herpesvirus 1 abortions based on diagnostic submissions to five U.S. based veterinary diagnostic laboratories. J. Vet. Diagn. Invest., 25: 243-247.

3. Fulton, R., d'Offay, J. and Eberle, R. (2013) Bovine herpesvirus-1: Comparison and differentiation of vaccine and field strains based on genomic sequence variation. Vaccine., 31: 1471-1419.

4. Shirvani, E., Lotfi, M., Kamalzadeh, M., Bahriari, M. and Abdoshah, M. (2011) Dot-blot enzyme immunoassay for the detection of bovine herpes virus-1(BHV-1) antibodies. World Appl. Sci. J., 15(6): 781-784.

5. Cabonero, A., Saa, L.R., Jara, D.V., Garcia-Bocanegra, I., Arenas, A., Borge, C. and Perea, A. (2011) Seroprevalence and risk factors associated to bovine herpes virus 1 (BHV-1) infection in non-vaccinated dairy and dual purpose cattle herds in ecuador. Prev. Vet. Med., 100(1): 84-88.

6. Iscan, U.T. and Duman, R. (2011) Bovine herpesvirus type 1 (BHV-1) prevalence in dairy cattle. J. Anim. Vet. Adv., 10(12): 1523-1525.

7. Roshtkhari, F., Mohammadi, G. and Mayameei, A. (2012) Serological evaluation of relationship between viral pathogens (BHV-1, BVDV, BRSV, PI-3V, and Adeno3) and dairy calf pneumonia by indirect ELISA. Trop. Anim. Health Prod., 44(5): 1105-1110.
8. Reed, L.V. and Muench, H. (1938) A simple method of evaluating fifty per cent end points. Am. J. Hyg., 27: 493.

9. Lowry, O.H., Rosebrough, N.J., Farr, A.L. and Randall, R.J. (1951) Protein measurement with Folin phenol reagent. $J$. Biol. Chem., 193: 265-275.

10. Florent, G. and Demarneffe, C.D. (1986) Enzyme linked immunosorbent assay used to monitor serum antibodies to bovine respiratory disease viruses. Vet. Microbiol., 11: 309-317.

11. Snedecor, G.M. and Cochran, W.G. (1967) Statistical Methods. $5^{\text {th }}$ ed. Iowa State University Press, Ames, Iowa.

12. Samal, S.K., Mallick, B.B. and Das, S.K. (1981) Note on the incidence of IBR virus infection among cattle in India. Indian J. Anim. Sci., 51(9): 895-897.

13. Suri Babu, T., Macllick, B.B. and Das, S.K. (1984) Prevalence of infectious bovine rhinotracheitis virus (BHV-1) antibodies in bovines. Indian Vet. J., 61: 195-200.

14. Raaperi, K., Nurmoja, I., Orro, T. and Viltrop, A. (2010) Seroepidemiology of bovine herpesvirus 1 (BHV-1) infection among Estonian dairy herds and risk factors for the spread within herds. Prev. Vet. Med., 96: 78-81.

15. Loretu, K., Marinov, P., Genov, I. and Bohnel, H. (1974) Virus isolations from cases on infectious bovine pustular vulvovagintis and posthitis (IPV/ IPB) in cattle in Tanzania. Bull. Epizoot. Dis. Afr., 22: 303-309.

16. Miller, J.M. (1991) The effects of IBR virus infection on reproductive function of cattle. Vet. Med., 1: 95-98.

17. Ampe, B., Duchateau, L., Speybroeck, N., Berkvens, D., Dupont, A. and Kerkhofs, P. (2012) Assessment of the longterm effect of vaccination on transmission of infectious bovine rhino tracheitis virus in cattle herds hyperimmunized with glycoprotein E-deleted marker vaccine. Am. J. Vet. Res., 73: 1787-1793.

18. Satyanarayana, K. and SuriBabu, T. (1987) Serological survey of bovine herpes virus - 1 (BHV-1), infection in bovines in Andhra Pradesh. Indian J. Anim. Sci., 57(6): 499-502.

19. Romero-Salas, D., Ahuja-Aguirre, C., Montiel-Palacios, F., García-Vázquez, Z., Cruz-Romero, A. and AguilarDomínguez, M. (2013) Seroprevalence and risk factors associated with infectious bovine rhinotracheitis in unvaccinated cattle in southern Veracruz, Mexico. Afr. J. Microbiol. Res., 7: 1716-1722.

20. Donkersgoed, J.C. and Babuik, L.A. (1991) Diagnosing and managing the respiratory form of infectious bovine rhinotracheitis. Vet. Med., 1: 86-98.

21. Straub, O.C. and Mackle, N. (1965) Ein ausbruch des blaschenausschlag in einer besamungsstation. Tierarztl. Umsch. 20: 113-116.

22. Dias, J.A., Alfieri, A.A., Ferreira-Neto, J.S., Gonçalves, V.S.P. and Muller, E.E. (2013) Seroprevalence and risk factors for bovine herpesvirus 1 infection in cattle herds in the state of Paraná, Brazil. Trans. Bound. Emerg. Dis., 60: 39-47.

23. Givens, M.D. (2012) Bull biosecurity: Diagnosing pathogens that cause infertility of bulls or transmission via semen. Clin. Theriogenol., 4: 302-307. 